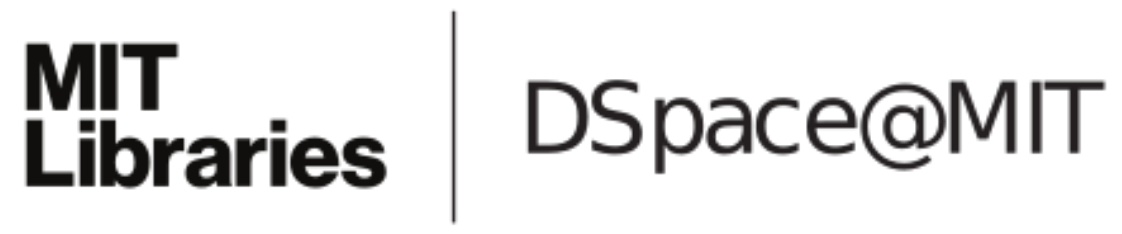

\author{
MIT Open Access Articles
}

Constraints on oxygen fugacity within metal capsules

The MIT Faculty has made this article openly available. Please share how this access benefits you. Your story matters.

Citation: Faul, Ulrich H., et al. "Constraints on Oxygen Fugacity within Metal Capsules." Physics and Chemistry of Minerals, vol. 45, no. 6, June 2018, pp. 497-509.

As Published: https://doi.org/10.1007/s00269-017-0937-7

Publisher: Springer Berlin Heidelberg

Persistent URL: http://hdl.handle.net/1721.1/116932

Version: Author's final manuscript: final author's manuscript post peer review, without publisher's formatting or copy editing

Terms of Use: Article is made available in accordance with the publisher's policy and may be subject to US copyright law. Please refer to the publisher's site for terms of use. 


\title{
Constraints on Oxygen Fugacity within Metal Capsules
}

\author{
Ulrich H. Faul • Christopher J. Cline II • \\ Andrew Berry · Ian Jackson • Gordana \\ Garapić
}

Received: date / Accepted: date

\begin{abstract}
Experiments were conducted with olivine encapsulated or wrapped in five different metals ( $\mathrm{Pt}, \mathrm{Ni}, \mathrm{Ni}_{70} \mathrm{Fe}_{30}, \mathrm{Fe}, \mathrm{Re}$ ) to determine the oxygen fugacity in the interior of large capsules used for deformation and seismic property experiments. Temperature $\left(1200^{\circ} \mathrm{C}\right)$, pressure $(300 \mathrm{MPa})$ and duration $(24 \mathrm{~h})$ were chosen to represent the most common conditions in these experiments. The oxygen fugacity was determined by analysing the Fe content of initially pure Pt particles that were mixed in with the olivine powder prior to the experiments. Oxygen fugacities in the more oxidizing metal containers are substantially below their respective metal-oxide buffers, with the $\mathrm{fO}_{2}$ of solgel olivine in $\mathrm{Ni}$ about 2.5 orders of magnitude below Ni-NiO. Analysis of olivine and metal blebs reveals three different length-, and hence diffusive time-scales: 1 . Fe loss to the capsule over $\sim 100 \mu \mathrm{m}$, 2. $\mathrm{fO}_{2}$ gradients at the sample-capsule interface up to $2 \mathrm{~mm}$ into the sample, and 3. constant interior $\mathrm{fO}_{2}$ values with an ordering corresponding to the capsule material. The inferred diffusive processes are: Fe diffusion in olivine with a diffusivity

U. Faul

Earth Atmospheric and Planetary Sciences, Massachusetts Institute of Technology, Cambridge, MA, USA E-mail: hufaul@mit.edu ORCID: 0000-0001-5036-4572

Also at: Research School of Earth Sciences, Australian National University, Canberra, Australia

C. Cline · A. Berry · I. Jackson

Research School of Earth Sciences, Australian National University, Canberra, Australia

G. Garapić

Department of Geology, SUNY New Paltz, NY, USA
\end{abstract}


$\sim 10^{-14} \mathrm{~m}^{2} / \mathrm{s}$, diffusion possibly of oxygen along grain boundaries with a diffusivity $\sim 10^{-12} \mathrm{~m}^{2} / \mathrm{s}$, and diffusion possibly involving pre-existing defects with a diffusivity $\sim 10^{-10} \mathrm{~m}^{2} / \mathrm{s}$. The latter, fast adjustment to changing $\mathrm{fO}_{2}$ may consist of a rearrangement of pre-existing defects, representing a metastable equilibrium, analogous to decoration of pre-existing defects by hydrogen. Full adjustment to the external $\mathrm{fO}_{2}$ requires atomic diffusion.

Keywords oxygen fugacity · olivine defects · diffusion · upper mantle

\section{Introduction}

2 It has long been recognized that the redox state of Earth's upper mantle is a 3 key parameter for models of its origin and evolution (e.g. O'Neill and Wall (1987); 4 Wood et al. (2009)). It affects the solidus in upwelling regions of the mantle, as well as the composition of the resulting melts and fluids (Ballhaus et al. 1991; Kelley and Cottrell 2009; Cottrell and Kelley 2011). Equally important is the oxidation state of C-O-H fluids in continental lithospheric mantle (Frost and McCammon 2008). For olivine, the oxygen fugacity $\left(\mathrm{fO}_{2}\right)$ determines the abundance of ferric iron, which is inferred to be a key defect that affects physical properties such as rheology (Kohlstedt and Mackwell 1998) and electrical conductivity (Karato 2011;

1 Yoshino and Katsura 2013; Tyburczy and Du Frane 2015). Since olivine dominates 12 the physical properties of the upper mantle, understanding its defect chemistry as 13 a function of $\mathrm{fO}_{2}$ is an important factor for the understanding of its dynamics.

In experiments control of $\mathrm{fO}_{2}$ is frequently approached by encapsulating sam5 ples in metal capsules, with or without deliberate addition of the corresponding 6 metal oxide. It is usually assumed that the $\mathrm{fO}_{2}$ of the sample interior is buffered 7 by the respective metal-metal oxide equilibrium, supported by the observation of 18 the oxide at the contact between capsules and sample (Hirth and Kohlstedt 1995; 19 Mei and Kohlstedt 2000; Wang et al. 2004; Tasaka et al. 2015).

While the $\mathrm{fO}_{2}$ in the interior of capsules that contain mostly melt or partially 21 molten samples has been experimentally assessed (Jamieson et al. 1992), this is not 
40 Two types of olivine were used in the experiments. The first type consists of 41 hand-picked and ground San Carlos (SC) olivine with a particle size of $2-10 \mu \mathrm{m}$ 42 from the same batch that contained $<0.01 \%$ melt in previous experiments (Faul

usually done for completely solid charges. To our knowledge, no experiments have been performed to determine the $\mathrm{fO}_{2}$ in the relatively large samples $(10-12 \mathrm{~mm}$ diameter and 20 - $35 \mathrm{~mm}$ in length) commonly used for hotpressing, deformation and seismic property experiments at pressures of $200-300 \mathrm{MPa}$ and temperatures up to $1300^{\circ} \mathrm{C}$ (Karato et al. 1986; Paterson 1990; Hirth and Kohlstedt 1995; Jackson et al. 2002). However, possible differences in $\mathrm{fO}_{2}$ between interior and sample edge of olivine enclosed by Fe jackets were discussed by Karato et al. (1986).

The experimental approach taken here is a variant of that used by Jamieson et al. (1992) and Rubie et al. (1993). These authors inserted or wrapped Pt wire around the experimental charges. Fe diffuses into this wire from the adjacent olivine by an amount that depends on $\mathrm{fO}_{2}$. However, due to the relatively large diameter of the wire, it represents a large sink for Fe and may not equilibrate with solid charges at the temperatures and durations of typical experiments $(\mathrm{Ru}-$ bie et al. 1993). In the experiments presented here, micron-sized Pt powder was mixed with the olivine powders prior to equilibration at high temperature and pressure. The $\mathrm{Pt}$ particles can then be analysed to produce $\mathrm{fO}_{2}$ transects through the samlpes.

\section{Experimental Approach} et al. 2004). The second type consists of Ti-doped Fogo solgel olivine (Faul et al. 2016). The composition of the solgel material was designed to contain excess silica and hence crystallize up to a few percent orthopyroxene (opx) to buffer the silica activity (see Section 4). Prior to cold-pressing into pellets, Pt powder (1\% by weight of the 2 g pellets) was added to both olivine types by 'folding' it through

the olivine powders using a spatula. This coarse mixing ensured the presence of agglomerated Pt particles large enough for analyses (see below). Post-run imaging 
shows that both types of olivine contain widely dispersed opx (see Section 3). The main difference between the two sample materials is that San Carlos olivine contains $\mathrm{Ni}$, Cr and a range of other trace elements (e.g. de Hoog et al. (2010)).

The pellets were pre-fired at an $\mathrm{fO}_{2}$ near the graphite-CO (CCO) buffer for 16 $\mathrm{h}$ at $1400^{\circ} \mathrm{C}$ (i.e. at an $\mathrm{fO}_{2} 0.2 \mathrm{log}$ units below CCO), and subsequently kept in a drying oven until loading. The cylindrical pellets measure $11.5 \mathrm{~mm}$ in diameter and $5 \mathrm{~mm}$ in length (except 6876: $8 \times 8 \mathrm{~mm}$ ) and are completely surrounded by a metal foil prior to insertion in a steel-jacketed assembly, as is done for deformation or seismic property experiments. In experiments with multiple pellets, adjacent metal-encapsulated pellets were separated by a $2 \mathrm{~mm}$ thick alumina disk which served to chemically isolate the different samples. The configuration of a four pellet experiment using as many different metal foils is shown in Figure 1. The mild steel jacket surrounding alumina pistons and sample assemblies with a wall thickness of $0.5 \mathrm{~mm}$ is of the same batch as those used for deformation and seismic property measurements in the ANU laboratory (e.g. Jackson et al. (2002); Faul and Jackson (2007)).

All samples were hotpressed for $24 \mathrm{~h}$ at $1200^{\circ} \mathrm{C}$ and $300 \mathrm{MPa}$ in a Paterson gas medium apparatus with Ar as the pressure medium. A mild steel jacket excludes the Ar pressure medium from sample assembly and alumina pistons (Figure 1, Paterson (1990)). The temperature uncertainty was estimated as $\pm 10^{\circ} \mathrm{C}$ along the length of the sample assembly from regular furnace calibrations. An exception is 6876 for which post experimental calibration showed a temperature gradient possibly as large as $80^{\circ} \mathrm{C}$. Post-run examination shows that the metal foils become welded at their touching points (i.e. the original interface can no longer be located in SEM images) and completely encapsulated the individual pellets without gaps. Table 1 summarizes the experiments and sample types.

Experiment 6707 was conducted to investigate the influence of direct contact between sample and Pt for water retention. For this purpose, two separate solgel pellets were wrapped in either $\mathrm{Ni}$ or $\mathrm{Ni}_{70} \mathrm{Fe}_{30}$ foil prior to insertion into a $\mathrm{Pt}$ 


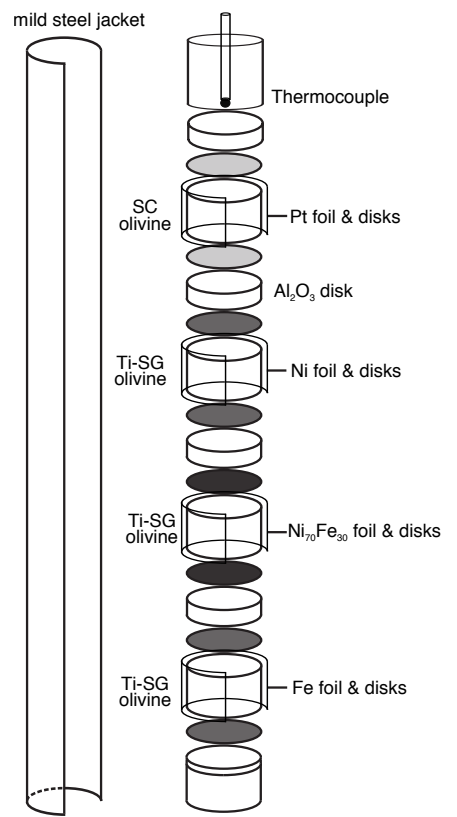

Fig. 1 Schematic of the assembly for experiment 6846 with four different metal enclosures of either Ti-doped solgel (SG) or San Carlos (SC) derived olivine pellets. The thermocouple is shown at the top. The height of the samples plus $\mathrm{Al}_{2} \mathrm{O}_{3}$ disks is about $38 \mathrm{~mm}$; furnace calibrations were conducted over $45 \mathrm{~mm}$ to a temperature difference $<5^{\circ} \mathrm{C}$. The two samples of run 6861 were similarly separated by an $\mathrm{Al}_{2} \mathrm{O}_{3}$ disk.

capsule that was then welded shut. Experiment 6805 was conducted to investigate water retention in capsules welded prior to insertion and pressurisation, compared to capsules where the foils where not welded prior to insertion. In this experiment, one pellet was welded, whereas the second was surrounded on three sides by $\mathrm{Pt}$, but left in direct contact with the alumina disk at the bottom. The observations are discussed in Section 6 .

Following hotpressing, the pellet stacks were sectioned axially, mounted in

The samples were analysed by standardised energy dispersive spectrometry using a Hitachi 4300 field emission SEM at the Centre for Advanced Microscopy 
Table 1 Summary of Experiments

\begin{tabular}{|c|c|c|c|c|c|c|}
\hline Experiment & Metal & $\begin{array}{c}\text { Foil } \\
\text { thickness, } \mathrm{mm}\end{array}$ & $\begin{array}{l}\text { Sample } \\
\text { type }\end{array}$ & $\begin{array}{c}\mathrm{Mg \#}^{a} \\
\text { int. }\end{array}$ & $\begin{array}{c}\mathrm{Mg}^{b} \\
\text { bleb }\end{array}$ & $\begin{array}{c}\mathrm{fO}_{2} \\
\log _{10}(\text { bars })^{c}\end{array}$ \\
\hline 6780 & $\mathrm{Pt}$ & $0.18 / 0.15^{d}$ & solgel & $89.6((5)$ & $89.7(3)$ & -9.5 \\
\hline \multirow[t]{4}{*}{6846} & $\mathrm{Pt}$ & $0.18 / 0.15$ & $\mathrm{SC}$ & $90.3(2)$ & $90.5(4)$ & -8.7 \\
\hline & $\mathrm{Ni}$ & 0.07 & solgel & $89.5(2)$ & $90.0(4)$ & -10.3 \\
\hline & $\mathrm{Ni}_{70} \mathrm{Fe}_{30}$ & 0.07 & solgel & $89.7(5)$ & $90.2(7)$ & -11.1 \\
\hline & $\mathrm{Fe}$ & 0.10 & solgel & $89.8(2)$ & $91.5(7)$ & -11.9 \\
\hline \multirow[t]{2}{*}{6861} & $\mathrm{Ni}$ & 0.07 & $\mathrm{SC}$ & $90.1(1)$ & $90.5(4)$ & -9.9 \\
\hline & $\mathrm{Fe}$ & 0.10 & $\mathrm{SC}$ & $90.0(1)$ & $92.6(3)$ & -11.4 \\
\hline 6876 & $\operatorname{Re}$ & 0.07 & solgel & $89.8(1)$ & $90.2(6)$ & -11.2 \\
\hline 6707 & $\mathrm{Pt}+\mathrm{Ni}, \mathrm{Pt}+\mathrm{NiFe}$ & $0.18+0.07$ & solgel & n.d. & n.d. & n.d. \\
\hline 6805 & Pt, Pt open & 0.18 & solgel & n.d. & n.d. & n.d. \\
\hline
\end{tabular}

All pellets were fired at $1400{ }^{\circ} \mathrm{C}$ for 16 hours with a gas mix consisting of $50 \% \mathrm{CO}$ and $50 \% \mathrm{CO}_{2}$. All experiments were conducted at $1200^{\circ} \mathrm{C}$ and $300 \mathrm{MPa}$ for 24

${ }_{a}^{\text {hours. }}$ Interior, far from metal blebs, average of 10 analyses for most samples.

${ }^{b}$ Next to metal blebs, average of 5 analyses.

${ }^{c}$ Interior $\mathrm{fO}_{2}$, calculated from metal blebs and adjacent olivine compositions. Average of at least 6 different blebs with at least three analyses for each bleb, Kessel et al. (2001) activities.

${ }^{d}$ Sides/end disks.

at the Australian National University with an acceleration voltage of $15 \mathrm{kV}$. The

beam current $(0.6 \mathrm{nA})$ was measured at regular intervals in a Faraday cup. Stan-

dards included oxides as well as pure metals; the latter were checked as part of the

analytical sessions. Additional analyses were performed using a JEOL-JXA-8200

electron microprobe at MIT with an acceleration voltage of $15 \mathrm{kV}$, a beam cur-

rent of $10 \mathrm{nA}$ and a beam diameter of $\sim 1 \mu \mathrm{m}$. Counting times were 20-40 s per

element, resulting in counting precisions of 0.5-1.0\% 1-sigma standard deviations.

The raw data were corrected for matrix effects with the CITZAF program (Armstrong 1995). Analyses of metal alloy blebs were also performed using a TESCAN

Vega 3 SEM with a Lab6 filament and an Oxford XMax50 EDS detector at SUNY

New Paltz, at $15 \mathrm{kV}$.

\section{Analytical Approach}

Compositional gradients from the deep sample interior towards the sample-capsule interface may have different spatial scales. For example, Fe gradients adjacent to 
Pt capsules in polycrystalline olivine without interconnected fluid phase extend over tens of microns (Watson 1991), requiring spacing of analyses of that order.

With sample diameters of 10-12 mm, gradients of the order of hundreds of microns also need to be resolved. In order to calculate $\mathrm{fO}_{2}$ fully quantitative point analyses are necessary. Therefore analyses of metal alloy blebs and adjacent olivine were performed in a transverse band near the middle of each cylindrical pellet up to the sample edges with a spacing of 0.1 to $0.5 \mathrm{~mm}$. Additionally, olivine in the interior far from any metal blebs was analyzed to document any Fe depletion adjacent to the metal blebs. At the sample-capsule interface, olivine was analysed at closely spaced $(10 \mu \mathrm{m})$ points over $150 \mu \mathrm{m}$. The analyses were continued with the same spacing for $50 \mu \mathrm{m}$ into the metal capsules to observe any diffusive gradients there. Due to diffusion of $\mathrm{Fe}$ into some of the metal foils from the jackets, axial traverses from sample into foil against the $\mathrm{Al}_{2} \mathrm{O}_{3}$ disks were also performed. The analytical approach is shown schematically in Figure 2.

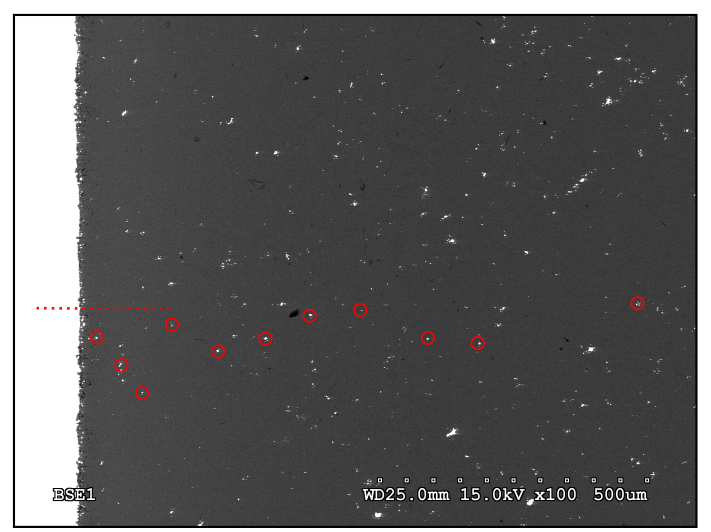

Fig. 2 Backscattered electron image of the sample-capsule interface of a solg-gel olivine sample in a $\mathrm{Ni}$ capsule (white/overexposed at left) showing schematically the analysis points for closely-spaced line-scans across the sample-capsule interface to determine diffusive Fe loss (dotted line). Circles schematically indicate analyses of alloy blebs and adjacent olivine. The latter are distributed in a centrally located radial band with a spacing as regular as possible, with a wider spacing in the interior. about $10 \mu \mathrm{m}$ as the smallest dimension of the often elongate shapes (Figure 3). 
yses per bleb were averaged.
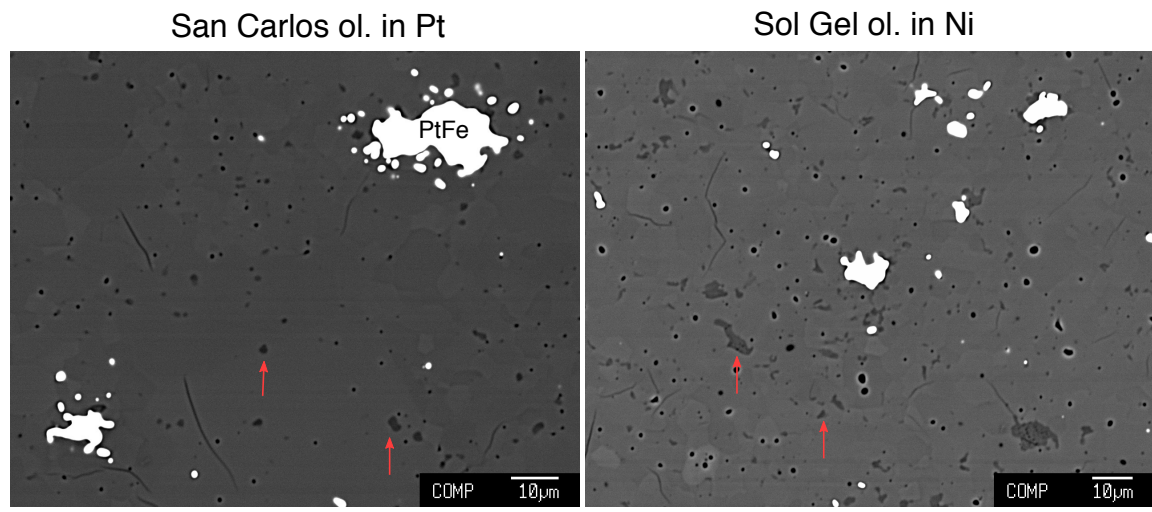

Fig. 3 Backscattered electron images of PtFe alloy blebs from two samples. Olivine shows minor orientation contrast. Red arrows indicate small orthopyroxene grains, confirming opx saturation. The blebs are randomly distributed throughout the samples; those larger than about $5 \mu \mathrm{m}$ were used for analysis.

\section{$4 \mathrm{Pt}$ as Oxygen Fugacity Sensor}

Petrologists noted early on that Fe loss occurred if Fe bearing samples were in contact with Pt metal (e.g. Bowen and Shairer (1932); Jaques and Green (1980); Grove (1981) and references therein). Fe (and Ni) uptake by Pt is a consequence of the solid solution between $\mathrm{Pt}$ and $\mathrm{Fe}(\mathrm{Ni})$. Pure $\mathrm{Pt}$ is therefore not in chemical equilibrium with $\mathrm{Fe}(\mathrm{Ni})$-bearing olivine. The composition of the resulting $\mathrm{PtFe}(\mathrm{Ni})$ metal alloy can be used to determine $\mathrm{fO}_{2}$ based on metal concentrations (activities) in the alloy and olivine (Jamieson et al. 1992; Rubie et al. 1993; O'Neill et al. 2003).

Equilibration of $\mathrm{Pt}$ with an Fe-bearing silicate allows calculation of the $\mathrm{fO}_{2}$ of the system from the equilibrium (Rubie et al. 1993):

$$
\mathrm{Fe}_{2} \mathrm{SiO}_{4}(\text { olivine })=2 \mathrm{Fe}(\text { metal })+\mathrm{O}_{2}+\mathrm{SiO}_{2}
$$


With the law of mass action the equilibrium constant for this reaction is:

$$
\mathrm{k}_{2}=\frac{\left(\mathrm{a}_{\mathrm{Fe}}^{\mathrm{met}}\right)^{2} \mathrm{a}_{2} \mathrm{a}_{\mathrm{SiO}_{2}}}{\mathrm{a}_{\mathrm{Fe}}^{\mathrm{ol}}} .
$$

1352

Equating the activity of oxygen $\mathrm{a}_{\mathrm{O}_{2}}$, with $\mathrm{fO}_{2}$, and taking the $\log _{10}$ of Equation 2 :

$$
\log \left(\mathrm{fO}_{2}\right)=\log \left(\mathrm{a}_{\mathrm{Fe}}^{\mathrm{ol}}\right)-2 \log \left(\mathrm{a}_{\mathrm{Fe}}^{\mathrm{met}}\right)-\log \left(\mathrm{a}_{\mathrm{SiO}_{2}}\right)+\log \left(\mathrm{k}_{2}\right)
$$

The activity of $\mathrm{Fe}$ in the PtFe alloy is given by $a_{F e}^{m e t}=\gamma_{F e}^{m e t} X_{F e}^{m e t}$, where $X_{F e}^{m e t}$ is the mole fraction of $\mathrm{Fe}$ in the alloy and $\gamma_{F e}^{m e t}$ is the activity coefficient of Fe. Similarly, the activity of the fayalite component in olivine on two sites per formula unit is obtained from: $a_{F e}^{o l}=\left(\gamma_{F e}^{o l} X_{F e}^{o l}\right)^{2}$ (Grove 1981; O'Neill et al. 2003).

In order to apply Equation 1 to Mg-bearing olivine a regular solution model was chosen with an interaction parameter $W_{M g-F e}^{o l}$ that is assumed to be independent of temperature and pressure for the experimental conditions (Jamieson et al. 1992; O'Neill et al. 2003). Further, pyroxene is treated as an ideal solution. While this is an approximation, Jamieson et al. (1992) noted that using different data for the equilibria involving olivine and pyroxene resulted in only small differences in the calculated $\mathrm{fO}_{2}$.

By contrast, the calculated $\mathrm{fO}_{2}$ is particularly sensitive to the Fe content (activity) of the PtFe alloy and its chosen activity model. Earlier work used the activitycomposition relationship of Heald (1967) for the PtFe alloy. Kessel et al. (2001) cited problems with this earlier approach, for both experimental/analytical as well as theoretical reasons. The largest differences between the methodology of Kessel et al. (2001) and Heald (1967) occur at low Fe contents in the alloy (oxidizing conditions) as the PtFe system shows a strong negative deviation from ideality at relatively high Pt contents. Additionally, differences between the studies increase with decreasing temperature, as the expression of Heald (1967) is temperatureindependent. The activity-composition relationship derived by Kessel et al. (2001) for an asymmetric regular solution of the PtFe alloy is given as: 


$$
\ln \gamma_{F e}^{m e t}=\left[W_{1}+2\left(W_{2}-W_{1}\right) X_{F e}^{m e t}\right]\left(X_{P t}^{m e t}\right)^{2} / \mathrm{RT}
$$

$\log \left(\mathrm{fO}_{2}\right)=2 \log \left(\gamma_{\mathrm{Fe}}^{\mathrm{ol}}\right)-2 \log \left(\gamma_{\mathrm{Fe}}^{\mathrm{met}}\right)+2 \log \left(\mathrm{X}_{\mathrm{Fe}}^{\mathrm{ol}} / \mathrm{X}_{\mathrm{Fe}}^{\mathrm{met}}\right)-\log \left(\mathrm{aSiO}_{2}\right)-\Delta \mathrm{G}^{0}(1)(\mathrm{P}, \mathrm{T}) / \ln (10) \mathrm{RT}$

with constants (Margules parameters) $W_{1}=138 \mathrm{~kJ} / \mathrm{mol}$ and $W_{2}=90.8 \mathrm{~kJ} / \mathrm{mol}$.

The activity of silica, $\mathrm{a}_{\mathrm{SiO}_{2}}$, can be calculated from the reaction:

$$
\begin{gathered}
\mathrm{Mg}_{2} \mathrm{SiO}_{4}+\mathrm{SiO}_{2}=\mathrm{Mg}_{2} \mathrm{Si}_{2} \mathrm{O}_{6} \\
\log \left(\mathrm{a}_{\mathrm{SiO}_{2}}\right)=\frac{\Delta \mathrm{G}^{0}(5)}{\ln (10) \mathrm{RT}}+\log \left(\mathrm{a}_{\mathrm{Mg}}^{\mathrm{opx}}\right)-\log \left(\mathrm{a}_{\mathrm{Mg}}^{\mathrm{ol}}\right)
\end{gathered}
$$

Since the Mg endmembers are the major components of the system, their activities are close to unity. The silica activity (in $\mathrm{J} / \mathrm{mol}$ ) as a function of pressure and temperature is then given by:

$$
\log \left(\mathrm{a}_{\mathrm{SiO}_{2}}\right)=-(6710+0.31 \mathrm{~T}+0.375 \mathrm{P}) / \ln (10) \mathrm{RT}
$$

where $\mathrm{P}$ is in bar and $\mathrm{T}$ in $\mathrm{K}$ (O'Neill and Wall 1987). The free energy of reaction $1, \Delta G^{0}(1)=-R T \ln \left(k_{2}\right)$, as a function of pressure and temperature is given by (in $\mathrm{J} / \mathrm{mol}$; Rubie et al. (1993)):

$$
\Delta \mathrm{G}^{0}(1)(\mathrm{P}, \mathrm{T})=5.65 \times 10^{5}-144 \mathrm{~T}-0.866 \mathrm{P} .
$$

\footnotetext{
Thus, equation 3 becomes:
}

The activity coefficient of Fe in olivine is calculated from:

$$
\ln \left(\gamma_{\mathrm{Fe}}^{\mathrm{ol}}\right)=\left(1-\mathrm{X}_{\mathrm{Fe}}^{\mathrm{ol}}\right)^{2}(600+0.0013 \mathrm{P}) / \mathrm{T}
$$


(Rubie et al. 1993). With different parameterisations for silica activity (Eq. 7; e.g. Holland and Powell (1989)) or $\Delta \mathrm{G}^{0}(1)$ (Eq. 8; O'Neill et al. (2003)) the calculated $\mathrm{fO}_{2}$ changes by less than $0.3 \log$ units.

\subsection{Defects}

An important aspect of Equation 1 is that the diffusion of Fe from sample to capsule releases oxygen, which changes the oxidation state of the sample (Merill and Wyllie 1973). The $\mathrm{O}_{2}$ released by Fe loss can react with olivine and pyroxene in a transfer reaction (c.f. Dohmen and Chakraborty (2007), Eq. 5a):

$$
3 \mathrm{Fe}_{\mathrm{M}}^{\mathrm{x}}+\mathrm{FeSiO}_{3}+\frac{1}{2} \mathrm{O}_{2}=\mathrm{V}_{\mathrm{M}}^{\prime \prime}+2 \mathrm{Fe}_{\mathrm{M}}^{\bullet}+\mathrm{Fe}_{2} \mathrm{SiO}_{4} .
$$

where in Kröger-Vink notation $V_{M}^{\prime \prime}$ represents an M-site vacancy, and $\mathrm{Fe}_{M}^{\bullet}$ represents $\mathrm{Fe}^{3+}$ on an M-site. This reaction increases the concentration of the majority defects in the charge neutrality condition (Stocker and Smyth 1978; Nakamura and Schmalzried 1983; Kohlstedt and Mackwell 1998):

$$
\left[\mathrm{Fe}_{\mathrm{M}}^{\bullet}\right]=2\left[\mathrm{~V}_{\mathrm{M}}^{\prime \prime}\right]
$$

The opx produced by Fe loss (Equations 1 and 5) may thus be offset by increasingly non-stoichiometric olivine.

A second transfer reaction involves $\mathrm{Fe}^{3+}$ both on the tetrahedral $\left(\mathrm{Fe}_{\mathrm{Si}}^{\prime}\right)$ and octahedral $\left(\mathrm{Fe}_{\mathrm{M}}^{\bullet}\right)$ sites (Eq. 5b of Dohmen and Chakraborty (2007)):

$$
\mathrm{Fe}_{\mathrm{M}}^{\mathrm{x}}+\mathrm{Si}_{\mathrm{Si}}^{\mathrm{x}}+\frac{1}{2} \mathrm{O}_{2}+\frac{1}{2} \mathrm{Fe}_{2} \mathrm{SiO}_{4}=\mathrm{Fe}_{\mathrm{M}}^{\bullet}+\mathrm{Fe}_{\mathrm{Si}}^{\prime}+\frac{3}{2} \mathrm{SiO}_{2} .
$$

Nakamura and Schmalzried (1983) assumed full association of $\mathrm{Fe}_{\mathrm{M}}^{\bullet}$ and $\mathrm{Fe}_{\mathrm{Si}}^{\prime}$, but in the model of Tsai and Dieckmann (2002) these two defects are not coupled. The charge neutrality condition is therefore expanded to: 


$$
\left[\mathrm{Fe}_{\mathrm{M}}^{\bullet}\right]=2\left[\mathrm{~V}_{\mathrm{M}}^{\prime \prime}\right]+\left[\mathrm{Fe}_{\mathrm{Si}}^{\prime}\right]
$$

At low $\mathrm{fO}_{2}$ the charge neutrality condition may involve electrons (Kohlstedt and Mackwell 1998):

$$
\left[\mathrm{Fe}_{\mathrm{M}}^{\bullet}\right]=\left[\mathrm{e}^{\prime}\right] .
$$

The point defect models developed by Nakamura and Schmalzried (1983) and Tsai and Dieckmann (2002) can be used to calculate concentrations of $\mathrm{Fe}^{3+}$ from the composition of olivine and $\mathrm{fO}_{2}$ derived in the previous section. With the model of Nakamura and Schmalzried (1983) for the case where $\mathrm{Fe}_{\mathrm{Si}}^{\prime}$ is negligible (i.e. charge neutrality condition Equation 12, and Equation 7a of Dohmen and Chakraborty (2007), see also Gaetani (2016)):

$$
\log \left[\mathrm{Fe}_{\mathrm{M}}^{\bullet}\right]=\frac{1}{6}\left(\log (\mathrm{K})+2 \log (2)+4 \log \left(\mathrm{X}_{\mathrm{Fe}}^{\mathrm{ol}}\right)+\log \left(\mathrm{fO}_{2}\right)+\log \left(\mathrm{a}_{\mathrm{SiO}_{2}}\right)\right)
$$

with reaction constant $\mathrm{K}$ calculated using equations 16 or $17 \mathrm{a}$ from Dohmen and Chakraborty (2007), and $\mathrm{a}_{\mathrm{SiO}_{2}}$ calculated from Equation 7 .

Including $\mathrm{Fe}_{\mathrm{Si}}^{\prime}$, the model of Tsai and Dieckmann (2002) predicts that this defect becomes more abundant than $\mathrm{Fe}_{\mathrm{M}}^{\bullet}$ at relatively high $\mathrm{fO}_{2}$ (Dohmen and Chakraborty 2007). The defect concentrations $\left[\mathrm{V}_{\mathrm{M}}^{\prime \prime}\right],\left[\mathrm{Fe}_{\mathrm{M}}^{\bullet}\right]$ and $\left[\mathrm{Fe}_{\mathrm{Si}}^{\prime}\right]$ can be calculated for case 6 of Dohmen and Chakraborty (2007) with their equation 18 and parameters from their Table 2 .

The absolute $\mathrm{Fe}^{3+}$ content calculated from the concentrations above is obtained from

$$
\mathrm{Fe}^{3+}=\frac{\left(\left[\mathrm{Fe}_{\mathrm{M}}^{\bullet}\right]+\left[\mathrm{Fe}_{\mathrm{Si}}^{\prime}\right]\right)}{2 \mathrm{X}_{\mathrm{Fe}}^{\mathrm{ol}}} \mathrm{Fe}_{\mathrm{t}}
$$

where $\mathrm{Fe}_{t}$ was determined by EDS or WDS analysis (i.e. all $\mathrm{Fe}$ counted as $\mathrm{FeO}$ ). 
Several aspects were considered for the analysis of olivine and metal blebs. While a minimum size for quantitative analysis of a few microns is necessary, the blebs were also intended to be small enough so that they can equilibrate diffusively with the surrounding olivine. This implies that the olivine near the blebs should not be Fe-depleted. A rough calculation shows that depleting a volume of olivine to account for the observed Fe content in the metal particles by less than the standard deviation of the olivine analyses requires a volume of olivine with a radius at least three times that of the particles (see also diffusion distances at the sample-capsule interface below). The analyses show that olivine compositions near the blebs in all but the Fe-enclosed samples were within one standard deviation of the olivine far from any blebs (Table 1). The slight Fe depletion of olivine adjacent to the blebs in Fe capsules is probably due to the higher amount of $\mathrm{Fe}$ in equilibrium with $\mathrm{Pt}$ at this low $\mathrm{fO}_{2}$. Ni is also depleted adjacent to the blebs and capsule for $\mathrm{Pt}$ and Fe encapsulated San Carlos olivine.

No opx rind is observable at the contact between samples and Pt and Ni foils. Topography of the blebs and fluorescence of the metal limits the proximity of the (olivine) analyses points near the blebs, as well as identification of a possible submicron opx rind. While all samples contain rounded pores, as is usually the case at this pressure (Jackson et al. 2002; Faul et al. 2004), these are randomly distributed along grain boundaries and as grain-interior inclusions. Near the edge $(<100 \mu \mathrm{m})$ of Pt-enclosed samples triangular-shaped pores at three-grain edges may indicate a locally connected porosity. The Re enclosed sample remained fine-grained and showed a high porosity, with pores randomly distributed.

Averaged from all analyses for all samples, San Carlos olivine in the interior has a slightly higher Mg-number of $90.2 \pm 0.17$, compared to solgel olivine (89.7 \pm 0.36$)$. 
5.1 Fe gradients at the Sample-Capsule Interface

Analyses of olivine at the sample-capsule interface are shown in Figure 4 and indicate significant loss of Fe to both Pt and Ni capsules. In M-site mole fractions, Fe decreases from $\sim 0.1$ in the interior to below 0.02 at the interface (i.e. an olivine Mg\# above 98), with lower values adjacent to Ni capsules compared to Pt capsules at the same distance from the interface. Fe depletion in Pt-enclosed olivine extends approximately $130 \mu \mathrm{m}$ into the sample, while in $\mathrm{Ni}$ foils the loss profile extends only to about $60 \mu \mathrm{m}$, indicating higher diffusivities of $\mathrm{Fe}$ in olivine within $\mathrm{Pt}$ capsules. Repeat analyses with WDS and EDS yield essentially identical results. The higher Fe content in the Pt capsule adjacent to solgel olivine is consistent with a somewhat lower $\mathrm{fO}_{2}$ compared to San Carlos olivine. These compositional differences between the two sample types are also observed in the interior (see Section 5.3).

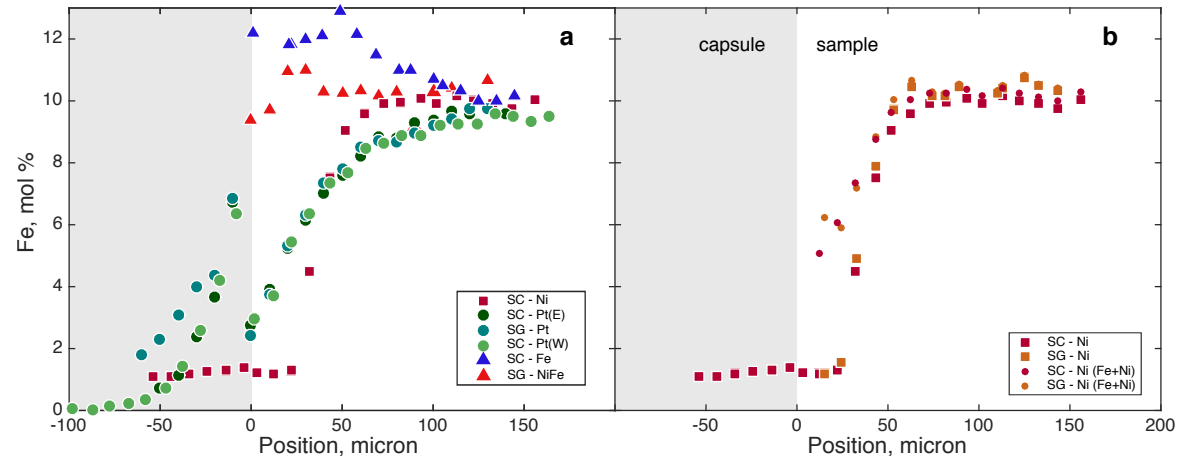

Fig. 4 Iron concentration gradients across the sample-capsule interface in different metal capsules. The interface is at zero $\mu \mathrm{m}$, negative values indicate analyses in the capsule (shown in gray). (a) Comparison of all capsule materials. The Pt encapsulated San Sarlos sample was analysed by both microprobe (WDS) and a FESEM (EDS). Fe depletion extends $\sim 130 \mu \mathrm{m}$ into the sample in the Pt capsule, but only about $60 \mu \mathrm{m}$ in Ni capsules. (b) Compositions in Ni-capsules. The small circles show the sum of $\mathrm{Ni}$ and Fe for the same analyses as the larger squares for Fe only. Cracks and metal blebs at the sample - capsule interface leads to some scatter in compositions (c.f. Figure 2), resulting in some cases in low totals for the analyses. Analyses for Re capsule are not shown, the olivine composition does not change leading up to the capsule. 
The Pt capsules show a Fe diffusion profile, with the concentration of Fe decreasing to zero within about $70-80 \mu \mathrm{m}$. By contrast the Fe concentration in Ni capsules with a foil thickness of $70 \mu \mathrm{m}$ is nearly constant across the capsule (for analyses adjacent to the $\mathrm{Al}_{2} \mathrm{O}_{3}$ disks). This indicates that diffusion of $\mathrm{Fe}$ in $\mathrm{Ni}$ as well as Pt is faster than in olivine, and Fe uptake in the capsule is controlled by Fe diffusion in olivine to the interface (Watson 1991). Rubie et al. (1993) similarly observed a Fe concentration gradient in both wire and olivine (their Figure 7).

Fe concentration profiles in olivine adjacent to $\mathrm{Ni}$ capsules indicate a step function-like change in composition. However, $\mathrm{Ni}$ diffuses from the capsule into olivine such that olivine adjacent to the capsule contains more than 5 wt. $\% \mathrm{NiO}$. When Ni and Fe are added, a smooth diffusion profile is observed (Figure 4b). The interface is therefore characterized by counterdiffusion of $\mathrm{Fe}$ and $\mathrm{Ni}$.

Within the detection limit of the WDS analyses, Fe-encapsulated San Carlos olivine next to the capsule shows a complete loss of $\mathrm{Ni}$, as well as Fe enrichment more than $100 \mu \mathrm{m}$ into the sample (Figure 4a). No significant change in olivine composition was observed in $\mathrm{Ni}_{70} \mathrm{Fe}_{30}$ foils, indicating near equilibrium with Fo90 olivine. Similarly, no change in composition is measurable for olivine in Re foil, and no measurable Fe was detected in the foil.

The Fe concentration gradients in both capsule and olivine also give an indication of the diffusion distances involved in the equilibration of the initially pure Pt particles with the surrounding olivine (see Section 5.3).

\section{$5.2 \mathrm{fO}_{2}$ Gradients at the Sample-Capsule Interface}

The metal alloy blebs dispersed in the samples allow direct determination of the oxygen fugacity throughout the capsules. The spatial scale over which the composition of the metal blebs changes from the interface to the interior is about one order of magnitude larger in comparison to that of Fe diffusion out of olivine. For Pt-encapsulated olivine the molar Fe content of the metal blebs, shown in Figure $5 \mathrm{a}$, decreases from the interior towards the capsule across the outermost $2 \mathrm{~mm}$ 


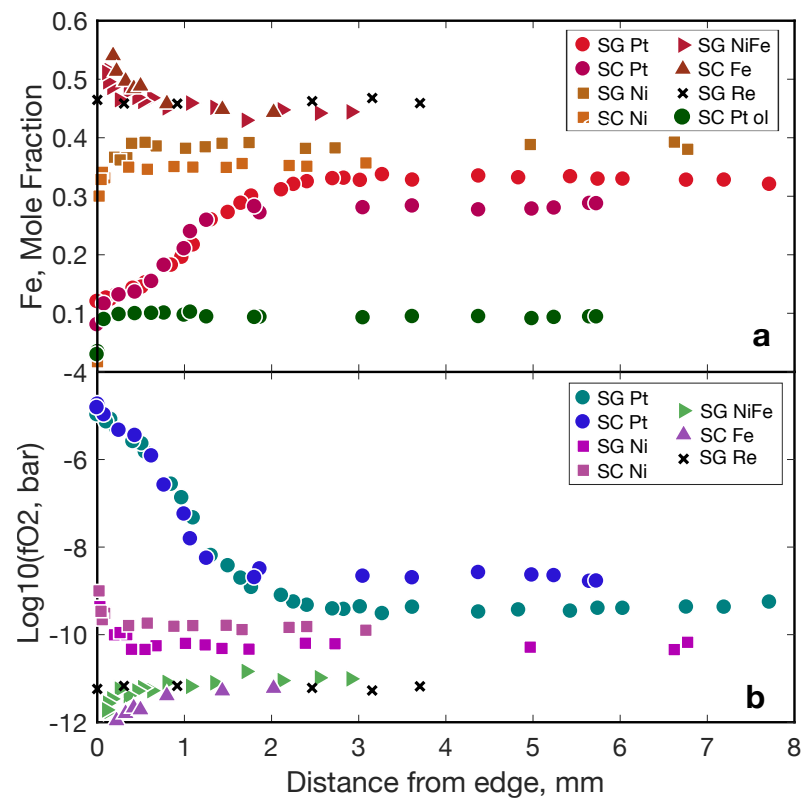

Fig. 5 Transects of metal alloy bleb compositions (a) and resulting $\mathrm{fO}_{2}$ (b). The samplecapsule interface is at zero $\mathrm{mm}$ at left. Only a representative olivine composition (San Carlos in a Pt capsule) is shown in (a). The change in olivine composition seen in Figure 4 is essentially unresolved at this scale. Compositional uncertainties are indicated by the variation of $\mathrm{Fe}$ and resulting $\mathrm{fO}_{2}$ in the interior for the individual capsules.

of radius. Ni-encapsulated samples show a similar decrease within the outermost

$0.4 \mathrm{~mm}$. An increase of the Fe concentration within the blebs towards the capsule is observed in NiFe and Fe capsules across an outer rim $<1 \mathrm{~mm}$ thick. As is emphasized by plotting olivine compositions adjacent to the blebs in Figure 5a, this change in metal alloy composition occurs at constant olivine composition.

The corresponding oxygen fugacities calculated from the alloy and olivine compositions with Equation 9 are shown in Figure 5b. Since the olivine compositions are constant at this scale, $\mathrm{fO}_{2}$ values follow the alloy compositions. From the interior to the edge of the Pt-enclosed samples $\mathrm{fO}_{2}$ increases by about 4 orders of magnitude, while the increase within the Ni capsule is less than one order of magnitude. $\mathrm{fO}_{2}$ values decrease approaching the $\mathrm{NiFe}$ and $\mathrm{Fe}$ capsules. 
$5.3 \mathrm{fO}_{2}$ in Sample Interiors

Metal alloy blebs within the deep interior of each of the variously enclosed samples have a constant composition without signs of diffusive gradients (Figure 5). However, as is shown in Figure 6, the $\mathrm{fO}_{2} \mathrm{~s}$ are different within different metal capsules. The $\mathrm{fO}_{2}$ of the $\mathrm{Fe}$ enclosed samples is near that of the corresponding metal-oxide buffer (Fe-wüstite, IW), but samples enclosed in Ni are more than two orders of magnitude more reduced than the $\mathrm{Ni}-\mathrm{NiO}$ buffer $(\mathrm{NNO})$. The $\mathrm{fO}_{2}$ in the interior of Pt enclosed samples is about one order of magnitude higher compared to Ni enclosed samples, and approaches the fayalite-magnetite-quartz (FMQ ) buffer for San Carlos olivine (containing Ni, Kessel et al. (2001) activity-composition relationships).

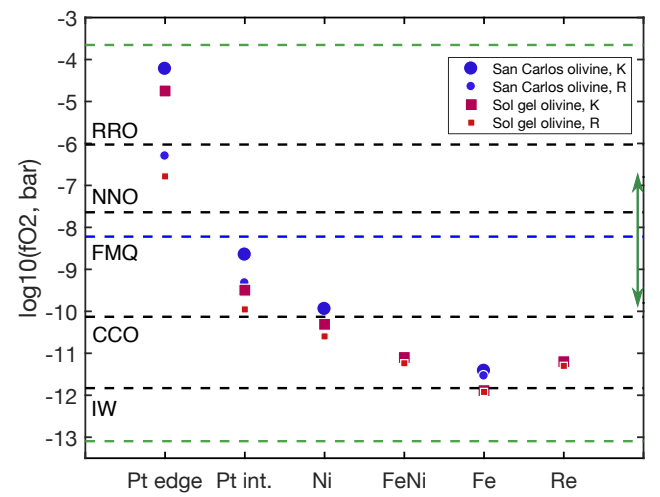

Fig. $6 \mathrm{fO}_{2}$ values in the deep sample interior and near the interface with the $\mathrm{Pt}$ capsule calculated from eq. 9. $\mathrm{K}$ indicates activities of Fe in the alloy from Kessel et al. (2001), R from Rubie et al. (1993) based on the data from Heald (1967). The two are nearly identical at the lowest $\mathrm{fO}_{2}$, but diverge significantly at the highest $\mathrm{fO}_{2}$. The green arrow indicates the range of mean $\mathrm{fO}_{2}$ values determined for mantle rocks from xenoliths and massifs in different tectonic settings, with subduction zones at the oxidizing end and some peridotite massifs at the reducing end (Frost and McCammon 2008). The abbreviations for the buffers are: RRO, Re-ReO ${ }_{2}$; NNO, Ni-NiO; CCO, C-CO; IW, Fe-FeO (black dashed lines), and QFM, quartzfayalite-magnetite (blue dashed line). The green dashed lines indicate the olivine stability field calculated from Dohmen and Chakraborty (2007), Appendix C. $\mathrm{fO}_{2}$ buffers were calculated from the compilation by Hirschmann et al. (2008), Re-ReO 2 from Pownceby and O'Neill (1994). 
in Figure 6 for the edge of the Pt encapsulated sample were calculated from the composition of the capsule and olivine immediately at the interface. Since the nearest blebs are usually a few tens of $\mu \mathrm{m}$ away from the interface their $\mathrm{fO}_{2}$ values are somewhat lower than that at the interface.

The Mg \# of olivine next to metal blebs are generally within one standard deviation of the analyses far from the blebs. Only in Fe capsules is olivine next to the blebs resolvably depleted in Fe (Table 1) as well as in Ni. This may be due to the higher Fe content of the metal alloy blebs in the Fe capsules (46 - 52 atomic\% in Fe vs 28 - 33 atomic\% in Pt capsules), necessitating longer diffusion distances and hence equilibration times.

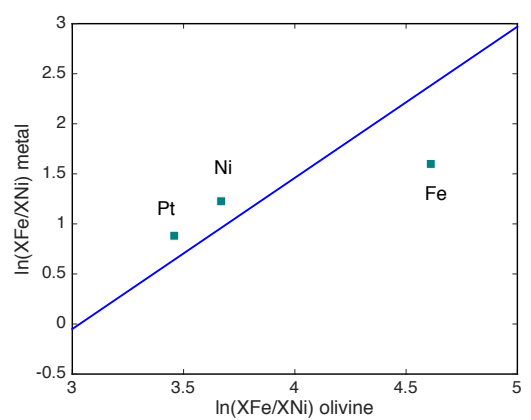

Fig. 7 Partitioning of $\mathrm{Fe}$ and Ni between metal alloy blebs and adjacent olivine in the interior of San Carlos olivine samples. The capsule materials are indicated next to the data points. The line represents equilibrium partitioning determined by Holzheid and Grove (2005).

The equilibration between metal blebs and olivine in the interior can be checked by comparison with equilibrium partitioning of $\mathrm{Fe}$ and $\mathrm{Ni}$ between metal and olivine determined by Holzheid and Grove (2005). Figure 7 shows a comparison of the fit to their data, obtained from a broad range of compositions, with the results of this study for the San Carlos olivine samples (solgel does not contain Ni). The agreement between the two studies is reasonable, confirming that the blebs are near equilibrium with the surrounding olivine. The largest deviation is observed for Fe capsules; a consequence of the Fe (and Ni) depletion noted above. The equilibrium 
$\mathrm{fO}_{2}$ values in Fe capsules are likely not substantially different however, due to the decreasing sensitivity at higher Fe contents in the alloy solution model.

\section{$5.4 \mathrm{Fe}^{3+}$ Content}

The $\mathrm{fO}_{2}$ calculated with the Kessel et al. (2001) activity-composition relations can be used to calculate the $\mathrm{Fe}^{3+}$ content of olivine using the defect models of Nakamura and Schmalzried (1983) and Tsai and Dieckmann (2002) (Section 4.1). Figure $8 \mathrm{a}$ shows that the concentrations of $\mathrm{Fe}_{\mathrm{M}}^{\bullet}$ calculated from the Nakamura and Schmalzried (1983) model for the charge neutrality condition not involving $\mathrm{Fe}_{\text {Si }}^{\prime}$ (Equation 12) are comparable to those calculated from Tsai and Dieckmann (2002) including this defect (Equation 14). The largest difference (0.4 log units) is predicted for the high $\mathrm{fO}_{2} \mathrm{~s}$ at the $\mathrm{Pt}$ interface, while at more reducing conditions the difference is less than $0.2 \log$ units. The salient difference between the two models is that Tsai and Dieckmann (2002) predict a crossover of the abundance of defects involving $\mathrm{Fe}^{3+}$ as a function of $\mathrm{fO}_{2}$ at $1200^{\circ} \mathrm{C}$. At high $\mathrm{fO}_{2}\left[\mathrm{Fe}_{\mathrm{Si}}^{\prime}\right]$ is higher; the crossover to higher $\left[\mathrm{Fe}_{\mathrm{M}}^{\bullet}\right]$ occurs near the $\mathrm{fO}_{2}$ in the sample interiors for Pt encapsulation.

The amount of $\mathrm{Fe}^{3+}$ calculated by adding $\left[\mathrm{Fe}_{\mathrm{Si}}^{\prime}\right]$ and $\left[\mathrm{Fe}_{\mathrm{M}}^{\bullet}\right]$ of the Tsai and Dieckmann (2002) model from Figure 8a is shown in Figure 8b. The high $\mathrm{Fe}^{3+}$ content at the Pt-sample interface is due to the high $\mathrm{Fe}_{\mathrm{Si}}^{\prime}$ for these oxidizing conditions. $\mathrm{Fe}^{3+}$ contents at lower $\mathrm{fO}_{2}$ in sample interiors are in the range of tens of ppm for both models; $\mathrm{fO}_{2}$ near IW still results in $\mathrm{Fe}^{3+}$ values above 10 ppm.

\section{Water Retention in Unbuffered Experiments}

As described in Faul et al. (2016), Ti-bearing, Pt enclosed olivine samples contain water after hotpressing and deformation experiments at high temperature. In these experiments water was preserved in an assembly with no hydrous components, without water having being deliberately added, or a dehydrating water buffer 

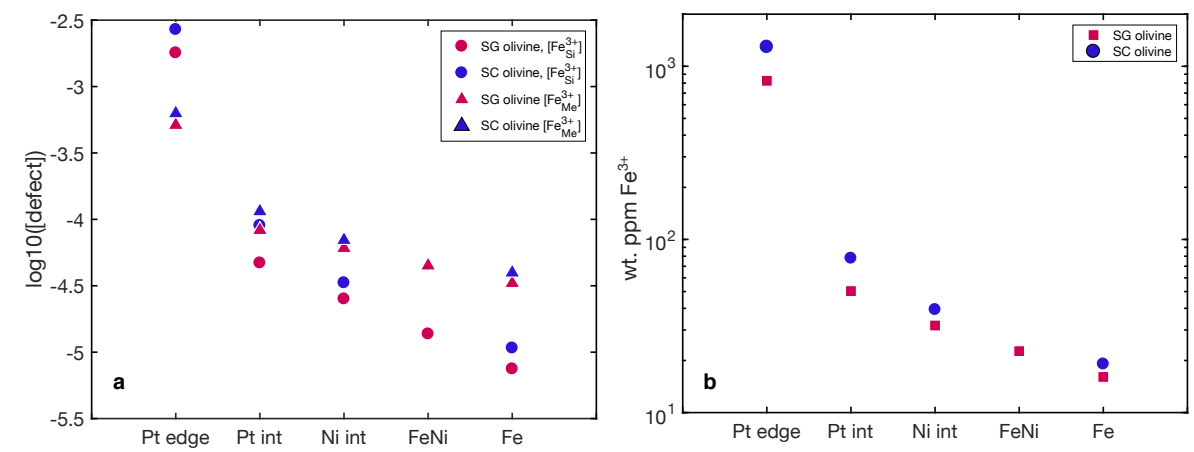

Fig. 8 (a) Defect concentrations of $\mathrm{Fe}_{\mathrm{M}}^{\bullet}$ and $\mathrm{Fe}_{\mathrm{Si}}^{\prime}$ for solgel and San Carlos olivine in the different capsules. At the high $\mathrm{fO}_{2} \mathrm{~s}$ at the interface of $\mathrm{Pt}$ foils the latter defect is more abundant, the cross-over occurs near the $\mathrm{fO}_{2} \mathrm{~s}$ of the interiors of Pt enclosed samples. (b) Total $\mathrm{Fe}^{3+}$ content in wt. ppm in both types of olivine. For comparison, San Carlos olivine typically contains about 20 wt. ppm Ti and 100 wt. ppm Cr (de Hoog et al. 2010); the solgel olivine of this study about 250 wt. ppm Ti. Fe ${ }^{3+}$ for the defect model of Tsai and Dieckmann (2002) (TD) were calculated with equations given in Dohmen and Chakraborty (2007) (Section 4.1). $\mathrm{fO}_{2} \mathrm{~s}$ were calculated with the Kessel et al. (2001) activity-composition relations.

having been used. The powders were fired in a controlled oxygen atmosphere after cold pressing and prior to loading. We tentatively infer that the water observed at the end of these experiments was introduced after firing by surface adsorption onto the fine-grained olivine powders, although ingress from the Argon gas surrounding the jacket may also be possible.

Figure 9 shows Fourier transform infrared spectroscopic (FTIR) maps of the water contents of olivine samples contained within welded and open Pt capsules in experiment 6805. The bottom of the pellet in Figure $9 \mathrm{~b}$ was left in direct contact with the alumina piston. The map shows that adjacent to the Pt water is retained, while some water is lost to the piston. Water retention therefore does not require prior welding of the capsule, only that the sample is completely surrounded by Pt. Further evidence that it is the direct contact between sample and Pt that leads to water retention is provided by an experiment (6707) where two pellets were separated from the $\mathrm{Pt}$ capsules by either $\mathrm{Ni}$ or $\mathrm{Ni}_{70} \mathrm{Fe}_{30}$ foil. FTIR spectroscopy showed that both samples were dry after hotpressing.

The water content of $\mathrm{Pt}$ encapsulated samples with added $\mathrm{Pt}$ particles was determined from FTIR transects across the center of the samples, similar to the 


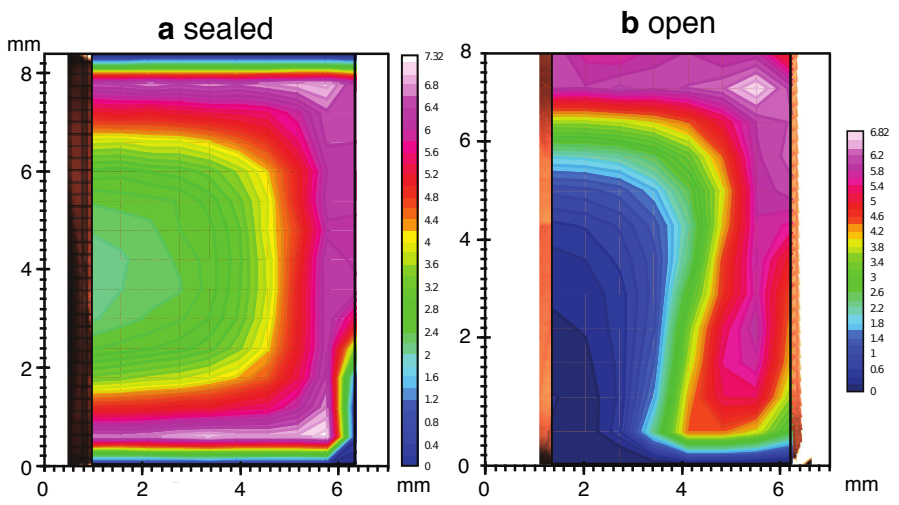

Fig. 9 FTIR maps of the Ti-hydroxyl content of two pellets hotpressed in the same experiment (6805) (a) The Pt capsule enclosing the pellet was welded shut prior to insertion in the assembly. (b) The pellet was wrapped in Pt foil and covered with a $\mathrm{Pt}$ disk at the top. The bottom was left in direct contact with the alumina piston. The numbers next to the colorscale indicate the the integrated absorbance, not the absolute values. The maximum water contents are $\sim 1300 \mathrm{ppm} \mathrm{H/Si}$. The maps show that welding of Pt capsules is not necessary for water retention.

$\mathrm{fO}_{2}$ transects. The region about $1.5 \mathrm{~mm}$ from the edge of the $\mathrm{Pt}$ encapsulated sample is optically darker, indicating oxidation (Rossman 1988). This region shows the increased $\mathrm{fO}_{2}$ (Figure 5) and the concomitant increase in the calculated $\mathrm{Fe}^{3+}$ content (Figure 8). The FTIR spectra recorded within $1.5 \mathrm{~mm}$ from the edge of the San Carlos olivine sample shown in Figure 10 include absorption bands around $3350 \mathrm{~cm}^{-1}$ and $3330 \mathrm{~cm}^{-1}$. These bands have been assigned to hydroxyl associated with trivalent cations, in particular $\mathrm{Fe}^{3+}$ and $\mathrm{Cr}^{3+}$ (Berry et al. 2007). The water content associated with these bands is small ( $<5$ wt. ppm $\mathrm{H}_{2} \mathrm{O}$ ), but implies that a significant fraction of the available $\mathrm{Fe}^{3+}$ is hydroxylated (c.f. Figure 8). Due to the relatively low water contents the spectra Figure 10 are relatively noisy, and the presence of $\mathrm{Fe}^{3+}$-related absorbance can not be confirmed unambiguously in the interior. FTIR spectra of both samples show absorption bands at 3525 and $3572 \mathrm{~cm}^{-1}$, attributed to Ti-related hydroxyl (Berry et al. 2005; Padrón-Navarta et al. 2014; Balan et al. 2011). The water contents associated with this defect are below 5 wt. ppm $\mathrm{H}_{2} \mathrm{O}$ in the San Carlos olivine samples due its low Ti content. 


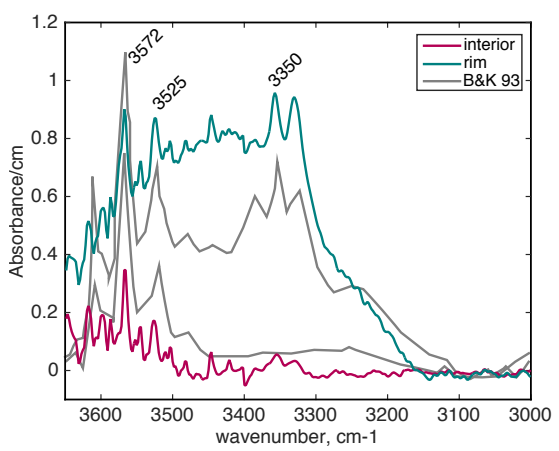

Fig. 10 Unpolarized FTIR spectra from the rim and interior of the San Carlos olivine pellet in a $\mathrm{Pt}$ capsule. The interior is nearly dry (hence the poor signal to noise ratio), while the rim shows both hydroxyl (structurally bound water) and molecular water (broad absorbance). The spectrum labelled 'rim' was acquired about $200 \mu \mathrm{m}$ from the sample-capsule interface, well within the oxidized region identifiable by the calculated $\mathrm{fO}_{2}$ (Figure 5) and is optically darker in the polished section. Spectra in grey are from Bai and Kohlstedt (1993), their Figure 2 , at similar $\mathrm{fO}_{2}$ as the interior and rim spectra, respectively, but from single crystals. Noticeable is the absence of the trivalent absorption bands at the lower $\mathrm{fO}_{2}$ for both single- and polycrystalline samples.

Bai and Kohlstedt (1993) obtained FTIR spectra from single crystals of San Carlos olivine that were heat-treated at water saturated conditions and different $\mathrm{fO}_{2} \mathrm{~s}$. The spectra they obtained at similar $\mathrm{fO}_{2} \mathrm{~s}$ as in the interior and the edge of the present samples are shown in Figure 10. Their spectra are similar to those from the present experiments, including the presence of the trivalent bands at high $\mathrm{fO}_{2}$. The only significant difference is the absence of the Si band at $3612 \mathrm{~cm}^{-1}$, which is attributed to the water-undersaturated conditions of the present experiments.

\section{Discussion}

With the same controlled atmosphere pre-treatment, the $\mathrm{fO}_{2}$ in the interior of the hot-pressed samples change by less than three orders of magnitude between Fe and Pt encapsulation. This compares with a nominal difference of more than ten orders of magnitude between the IW and the (theoretical) Pt-PtO 2 buffers. The increasing $\mathrm{fO}_{2} \mathrm{~s}$ from the interface to the interior for reducing foils and decreasing $\mathrm{fO}_{2} \mathrm{~s}$ for oxidizing foils (Figure 5) suggests that the samples are to some extent self-buffering during the 24 hour exposure to the hot-pressing conditions. This 
is supported by the observation that $\mathrm{Ni}$ and $\mathrm{Cr}$ containing San Carlos olivine experiences a somewhat higher $\mathrm{fO}_{2}$ in comparison to trace element-free (except $\mathrm{Ti}$ ) solgel olivine in the same metal capsule and following the same pre-treatment. Thermodynamic modelling shows that the presence of $\mathrm{Ni}$ increases the lower $\mathrm{fO}_{2}$ stability limit in comparison to Ni-free olivine (Matas et al. 2000). The Re enclosed sample with an interior $\mathrm{fO}_{2}$ similar to the $\mathrm{Fe}$ and $\mathrm{FeNi}$ enclosed samples (Figure 6) and in the absence of any measurable reaction with the Re foil also indicates self buffering. The Re- $\mathrm{ReO}_{2}$ buffer is at a higher $\mathrm{fO}_{2}$ compared to NNO, but inertness of Re metal is likely the reason why the interior $\mathrm{fO}_{2}$ does not follow the order of the other samples relative to their metal-oxide buffers. The lack of adjustment of the Re enclosed sample confirms that it is the Fe loss to Pt and Ni capsules releasing $\mathrm{O}_{2}$ that leads to the observed $\mathrm{fO}_{2}$ gradient into the interior.

A mechanism for self-buffering may be provided by Equations 11 and 13 for the case where opx is present. $\mathrm{O}_{2}$ produced by reducing $\mathrm{Fe}^{3+}$ in reaction 11 maybe consumed in reaction 13 , producing $\mathrm{Fe}^{\prime}{ }_{\mathrm{Si}}$.

The $\mathrm{fO}_{2}$ at the interface of $\mathrm{Pt}$ and $\mathrm{Ni}$ containers is continuously evolving during the experiments due to the Fe uptake by the containers. The calculated $\mathrm{Fe}^{3+}$ amounts (Figure 8b) indicate that intrinsic defects are comparable in abundance to extrinsic defects of for example 100 wt. ppm Cr in San Carlos olivine (de Hoog et al. 2010).

For San Carlos olivine the compositions of the blebs represent a ternary system (Pt-Fe-Ni). However, no data for activity-composition relations in this ternary system exist. In the absence of such data the best possible approach is to extrapolate from the three binary systems. If in particular $X_{N i}^{m e t}$ is small, the corresponding Fe-Ni interactions will be small. Additionally, the Fe-Ni binary is closer to ideality than either Fe-Pt or Ni-Pt (Cacciamani et al. 2010). For San Carlos olivine we therefore follow the approach of Rubie et al. (1993) using the measured compositions of the blebs without normalisation to a binary composition. The analytical results also show that the $\mathrm{Ni}$ content of the blebs is the same for all capsule 
materials (Supplementary Data), independent of $\mathrm{fO}_{2}$. This indicates that the $\mathrm{Ni}$ content is limited by the low concentration in olivine and consequently necessary diffusion distance, rather than equilibration of the system. For the interior of solgel olivine samples all observations and conclusions can be based on the Ni-free binary system.

\subsection{Diffusivities}

Of the diffusive processes identified in Section 5, Fe diffusion is the slowest, with diffusion distances ranging from tens of $\mu \mathrm{m}$ in $\mathrm{Ni}$ and FeNi foils to $>100 \mu \mathrm{m}$ in $\mathrm{Pt}$ and Fe foils. The diffusivity estimated from the diffusion profile of Fe in the $\mathrm{Pt}$ capsule is of order $10^{-14} \mathrm{~m}^{2} / \mathrm{s}$. Measured grain boundary diffusivities of Fe are about one order of magnitude faster (Dohmen and Milke 2010). The slower value observed here is likely to reflect a combination of grain boundary and grain interior diffusivity. In Ni capsules, the Fe diffusion profile is affected by counter-diffusion of Ni (Figure 4); the diffusivity is lower compared to Pt capsules.

Equation 1 shows that Fe loss from olivine to the metal capsules produces oxygen, which can diffuse into the sample. Oxygen diffusion from the sample-capsule interface into the interior is suggested by the changing metal bleb compositions and corresponding $\mathrm{fO}_{2}$ profile in Figure 5. This profile indicates diffusivities of the order of $10^{-12} \mathrm{~m}^{2} / \mathrm{s}$, which is similar to measured grain boundary diffusivities of oxygen in olivine (Condit et al. 1985; Dohmen and Milke 2010). This indicates that experimental assemblies with a metal-oxide buffer at the outside or one end of a sample do not guarantee that the sample interior is at this oxygen buffer. The time-scale required for equilibration of the $\mathrm{fO}_{2}$ appears to be that of grain boundary diffusion of oxygen.

With a diffusivity of $10^{-12} \mathrm{~m}^{2} / \mathrm{s}$ at $1200 \mathrm{C}$ cylindrical samples with a diameter of $2 \mathrm{~mm}$ should come close to equilibrium with an oxygen buffer surrounding the sample over 24 hours. Lower temperatures or larger samples will require correspondingly longer experimental durations. 
The differences in $\mathrm{fO}_{2}$ between the interiors of the differently encapsulated samples imply that the deep interior of the sample is sensitive to the external conditions during hotpressing. The absence of diffusion profiles for this process in the sample traverses (Figure 5) implies a diffusive process that is at least two orders of magnitude faster than the process controlling oxygen diffusion, of the order of $10^{-10} \mathrm{~m}^{2} / \mathrm{s}$. Such high diffusivities are variously ascribed to metal vacancies (Mackwell et al. 1988), hydrogen (protons), polarons (hopping of the charge of $\mathrm{Fe}^{3+}$ defects, Sato (1986)) and electrons (see e.g. Demouchy and Bolfan-Casanova (2016).

\subsection{A 'Metastable' Oxygen Fugacity?}

Fast hydration of pre-existing defects ( $\operatorname{such}$ as $\mathrm{V}_{\mathrm{M}}^{\prime \prime}$ ) is inferred to occur by diffusion of interstitial protons, charge compensated by a counterflux of polarons ( $\mathrm{Fe}_{\mathrm{M}}^{\bullet}$ ) (Mackwell and Kohlstedt 1990). Kohlstedt and Mackwell (1998) refer to the process of exchanging protons with polarons as a metastable equilibration, and distinguish it from incorporation of hydroxyl, resulting in an equilibrium concentration of $\mathrm{H}$ for a given water fugacity (see also Tollan et al. (2017)). Diffusivities of protons and polarons at $1200^{\circ} \mathrm{C}$ are of the order of $10^{-8} \mathrm{~m}^{2} / \mathrm{s}$ (Demouchy et al. 2016), while the creation of hydrated Si defects requires (local) Si diffusion (Karato 2008 ) and is substantially slower (of the order of $10^{-13} \mathrm{~m}^{2} / \mathrm{s}$, Padrón-Navarta et al. (2014)).

Mackwell et al. (1988) conducted creep experiments with San Carlos olivine in a controlled atmosphere furnace at high temperature. In these experiments constant stress was maintained while the oxygen partial pressure was changed. The time to reach steady state creep after a change in $\mathrm{fO}_{2}$ was interpreted as the equilibration time of grain-internal defects with the externally imposed $\mathrm{fO}_{2}$, allowing calculation of defect diffusivities. The resulting diffusivities are of the order of $10^{-10} \mathrm{~m}^{2} / \mathrm{s}$ at $1200^{\circ} \mathrm{C}$. Mackwell et al. (1988) inferred that the rapid equilibration to the externally imposed $\mathrm{fO}_{2}$ was due to diffusion of vacancies rather 
than atoms, since the diffusivities are comparable to metal vacancy diffusivities determined previously (Nakamura and Schmalzried 1984; Wanamaker 1994).

The present experiments show a fast adjustment of the interior $\mathrm{fO}_{2}$ to different metal capsules, with a diffusivity that is comparable to that inferred for vacancy diffusion. However, the new $\mathrm{fO}_{2}$ does not correspond to the respective metal-oxide buffers, while the $\mathrm{fO}_{2}$ gradients observed at the sample-metal interfaces indicate ongoing adjustments to the conditions at the interface. This suggests that, similar to hydration reactions, rapid but 'metastable' changes in $\mathrm{fO}_{2}$ can occur, involving pre-existing defects. A possibility is a change in the distribution of $\mathrm{Fe}^{3+}$ between $\mathrm{Fe}_{\mathrm{M}}^{\bullet}$ and $\mathrm{Fe}_{\mathrm{Si}}^{\prime}$ as a function of $\mathrm{fO}_{2}$ (Equations 11 and 13, Tsai and Dieckmann (2002)). Since $\mathrm{Fe}_{\mathrm{M}}^{\bullet}$ is more mobile than $\mathrm{Fe}_{\mathrm{Si}}^{\prime}$ this redistribution may affect the rheology (Mackwell et al. 1988) and electrical conductivity (Roberts and Tyburczy 1993).

Full equilibration requires creation of new defects, involving an olivine grainexternal component (pyroxene), as well as $\mathrm{O}_{2}$ from an external source (c.f. Eq. 5a of Dohmen and Chakraborty (2007); see also Karato (2008)). In the present experiments opx is well mixed with olivine (Figure 3) at the scale of tens of $\mu \mathrm{m}$. Particularly for experiments with single crystals significantly larger diffusion distances for silica equilibration may be involved.

\section{Summary and Application}

Experiments with samples of polycrystalline olivine including dispersed, small Pt particles as $\mathrm{fO}_{2}$ sensors show that the sample-interior $\mathrm{fO}_{2}$ does not correspond to the nominal $\mathrm{fO}_{2}$ of the metal foils and their oxides surrounding the samples. After having received the same pre-treatment in a 1 atm furnace, the sample interior $\mathrm{fO}_{2}$ after hotpressing differs for different metal foils, but is restricted to a comparatively narrow range. Gradients in $\mathrm{fO}_{2}$ occur at the metal-foil interfaces with a spatial scale about an order of magnitude larger compared to diffusive Fe loss to the capsules. From these observations three different diffusive spatial/time 
scales can be identified: Fe loss extending over tens of $\mu \mathrm{m}$; gradients in $\mathrm{fO}_{2}$ of up to $2 \mathrm{~mm}$; and constant, but different $\mathrm{fO}_{2} \mathrm{~s}$ in the interiors of the capsules. Together these observations indicate the possibility of fast but 'metastable' adjustments to $\mathrm{fO}_{2}$, similar to hydration reactions of pre-existing defects. Full equilibration of the $\mathrm{fO}_{2}$ is not governed by defect diffusion, but requires atomic diffusion.

There is no doubt that the generally more oxidising conditions prevailing within and particularly at the edge of $\mathrm{Pt}$ capsules, and to a lesser extent $\mathrm{Ni}$, capsules are broadly conducive to the retention of water - whether as bound hydroxyl or molecular water (Faul et al. 2016). Utilizing these capsule materials to retain water, a recent forced oscillation study of seismic wave dispersion and attenuation in polycrystalline olivine (Cline II et al. 2017) demonstrated that the seismic properties are sensitive neither to bound hydroxyl nor molecular water. Instead, the use of alternative $\mathrm{Pt}, \mathrm{Ni}$, and $\mathrm{Ni}_{70} \mathrm{Fe}_{30}$ sleeves together with solgel and San Carlos olivine has been exploited in this study to show that seismic properties vary systematically with oxygen fugacity.

Acknowledgements: The authors would like to acknowledge insightful discussions with Hugh O'Neill over many years on this topic. This work was in part funded by NSF grant EAR 1321889 to U.F. and ARC grant DP130103848 to I.J, A.B., U.F. and S. Karato. The authors thank Harri Kokkonen and Hayden Miller for technical assistance. The comments of Vladimir Matjuschkin and an anonymous reviewer helped to improve the manuscript . 


\section{References}

Armstrong, J. T., 1995. CITZAF - a package for correction programs for the quantitative electron microbeam x-ray analysis of thick polished materials, thin-films and particles. Microbeam Anal. 4, 177-200.

Bai, Q., Kohlstedt, D. L., 1993. Effects of chemical environment on the solubility and incorporation mechanism for hydrogen in olivine. Physics and Chemistry of Minerals 19, 460 471.

Balan, E., Ingrin, J., Delattre, S., Kovacs, I., Blanchard, M., 2011. Theoretical infrared spectrum of oh defects in forsterite. European Journal of Mineralogy 23, 285-292.

Ballhaus, C., Berry, R. F., Green, D. H., 1991. High pressure experimental calibration of the olivine-orthopyroxene-spinel oxygen geobarometer: implications for the oxidation state of the upper mantle. Contributions to Mineralogy and Petrology 107, $27-40$.

Berry, A. J., Hermann, J., O’Neill, H. S. C., Foran, G. J., 2005. Fingerprinting the water site in mantle olivine. Geology 33, 869-872; doi: 10.1130/G21759.1.

Berry, A. J., O'Neill, H. S. C., Hermann, J., Scott, D. R., 2007. The infrared signature of water associated with trivalent cations in olivine. Earth and Planetary Science Letters 261, 134-142.

Bowen, N. L., Shairer, J. F., 1932. The system FeO - $\mathrm{SiO}_{2}$. American Journal of Science 5th series, $24,177-213$.

Cacciamani, G., Dinsdale, A., Palumbo, M., Pasturel, A., 2010. The fe-ni system: Thermodynamic modelling assisted by atomistic calculations. Intermetallics 18, 1148 - 1162 .

Cline II, C. J., Faul, U. H., David, E. C., Berry, A. J., Jackson, I., 2017. Redox-influenced seismic properties of upper-mantle olivine. in review.

Condit, R. H., Weed, H. C., Piwinskii, A. J., 1985. A technique for observing oxygen diffusion along grain boundary regions in synthetic forsterite. In: Schock, R. N. (Ed.), Point Defects in Minerals. Vol. 31 of Geophysical Monographs. American Geophysical Union, pp. 97 105.

Cottrell, E., Kelley, K. A., 2011. The oxidation state of Fe in MORB glasses and the oxygen fugacity of the upper mantle. Earth and Planetary Science Letters 305, $270-282$.

de Hoog, J. C. M., Gall, L., Cornell, D. H., 2010. Trace-element geochemistry of mantle olivine and application to mantle petrogenesis and geothermobarometry. Chemical Geology 270, 196-215, doi:10.1016/j.chemgeo.2009.11.017.

Demouchy, S., Bolfan-Casanova, N., 2016. Distribution and transport of hydrogen in the lithospheric mantle: A review. Lithos 240 - 243, 402 - 425.

Demouchy, S., Thoraval, C., Bolfan-Casanova, N., Manthilake, G., 2016. Diffusivity of hydrogen in iron-bearing olivine at 3 gpa. Physics of the Earth and Planetary Interiors 260, 1 - 13. 
Dohmen, R., Chakraborty, S., 2007. Fe-Mg diffusion in olivine II: point defect chemistry, change of diffusion mechanisms and a model for calculation of diffusion coefficients in natural olivine. Physics and Chemistry of Minerals 34, $409-430$.

Dohmen, R., Milke, R., 2010. Diffusion in polycrystalline materials: Grain boundaries, mathematical models, and experimental data. Reviews in Mineralogy and Geochemistry 72 , $921-970$

Faul, U. H., Cline II, C. J., David, E. C., Berry, A. J., Jackson, I., 2016. Titatnium-hydroxyl defect-controlled rheology of the Earth's upper mantle. Earth and Planetary Science Letters 452 (dx.doi.org/10.1016/j.epsl.2016.07.016), $227-237$.

Faul, U. H., Fitz Gerald, J. D., Jackson, I., 2004. Shear wave attenuation and dispersion in melt-bearing olivine polycrystals: 2. microstructural interpretation and seismological implications. Journal of Geophysical Research 109, B06202, doi:10.1029/2003JB002407.

Faul, U. H., Jackson, I., 2007. Diffusion creep of dry, melt-free olivine. Journal of Geophysical Research 110, B04204, doi:10.1029/2006JB004586.

Frost, D. J., McCammon, C. A., 2008. The redox state of Earth's mantle. Annual Reviews of Earth Planetary Sciences 36, 389 - 420.

Gaetani, G. A., 2016. The behavior of $\mathrm{Fe}^{3+} / \sum \mathrm{Fe}$ during partial melting of spinel lherzolite. Geochimica et Cosmochimica Acta 185, 64 - 77, http://dx.doi.org/10.1016/j.gca.2016.03.019.

Grove, T. L., 1981. Use of fept alloys to eliminate the iron loss problem in 1 atmosphere gas mixing experiments: Theoretical and practical considerations. Contributions to Mineralogy and Petrology 78, $298-304$.

Heald, E. F., 1967. Thermodynamics of iron-platinum alloys. Trans. Metall. Soc. AIME $239(1337-1340)$

Hirschmann, M. M., Ghiorso, M. S., Davis, F. A., Gordon, S. M., Mukherjee, S., Grove, T. L., Krawczynski, M., Medard, E., Till, C. B., 2008. Library of Experimental Phase Relations (LEPR): A database and Web portal for experimental magmatic phase equilibria data. Geochem. Geophys. Geosyst. 9, doi:10.1029/2007GC001894.

Hirth, G., Kohlstedt, D. L., 1995. Experimental constraints on the dynamics of the partially molten upper mantle: 1. Deformation in the diffusion creep regime. Journal of Geophysical Research 100, $1981-2001$.

Holland, T. J. B., Powell, R., 1989. An internally consistent thermodynamic data set for phases of petrological interest. Journal of Metamorphic Geology 16, $309-343$.

Holzheid, A., Grove, T. L., 2005. The effect of metal composition on Fe-Ni partition behavior between olivine and FeNi-metal, FeNi-carbide, FeNi-sulfide at elevated pressure. Chemical Geology 221, $207-224$. 
Jackson, I., Gerald, J. D. F., Faul, U. H., Tan, B. H., 2002. Grain-size-sensitive seismic wave attenuation in polycrystalline olivine. Journal of Geophysical Research 107, doi:10.1029/2001JB001225.

Jamieson, H. E., Roeder, P. L., Grant, A. H., 1992. Olivine-pyroxene-PtFe alloy as oxygen geobarometer. Journal of Geology 100, 138 - 145.

Jaques, A. L., Green, D. H., 1980. Anhydrous melting of peridotite at 0-15 kb pressure and the genesis of tholeiitic basalts. Contributions to Mineralogy and Petrology 73, 287-310. Karato, S. I., 2008. Deformation of Earth Materials. Cambridge University Press.

Karato, S. I., 2011. Water distribution across the mantle transition zone and its implications for global material circulation. Earth and Planetary Science Letters 301, 413-423.

Karato, S. I., Paterson, M. S., Fitz Gerald, J. D., 1986. Rheology of synthetic olivine aggregates: Influence of grain size and water. Journal of Geophysical Research 91, 8151 - 8176.

Kelley, K. A., Cottrell, E., 2009. Water and the oxidation state of subduction zone magmas. Science $325,605-607$.

Kessel, R., Beckett, J. R., Stolper, E. M., 2001. Thermodynamic properties of the Pt-Fe system. American Mineralogist 86, 1003 - 1014.

Kohlstedt, D. L., Mackwell, S. J., 1998. Diffusion of hydrogen and intrinsic point defects in olivine. Zeitschrift für physikalische Chemie 207, 147 - 162.

Mackwell, S. J., Dimos, D., Kohlstedt, D. L., 1988. Transient creep of olivine: Point-defect relaxation times. Philosopical Magazine A 57, 779 - 789.

Mackwell, S. J., Kohlstedt, D. L., 1990. Diffusion of hydrogen in olivine: Implicationsfor water in the mantle. Journal of Geophysical Research 95, 5079-5088.

Matas, J., Ricard, Y., Lemelle, L., Guyot, F., 2000. An improved thermodynamic model of metal-olivine-pyroxene stability domains. Contributions to Mineralogy and Petrology 140, $73-83$.

Mei, S., Kohlstedt, D. L., 2000. Influence of water of plastic deformation of olivine aggregates: 1. Diffusion creep regime. Journal of Geophysical Research 105, 21,475 - 21,469.

Merill, R. B., Wyllie, P. J., 1973. Absorption of iron by platinum capsules in high pressure rock melting experiments. American Mineralogist 58, 16 - 20.

Nakamura, A., Schmalzried, H., 1983. On the nonstoichiometry and point defects of olivine. Physics and Chemistry of Minerals 10, $27-37$.

Nakamura, A., Schmalzried, H., 1984. On the $\mathrm{Fe}^{2+}-\mathrm{Mg}^{2+}$-interdiffusion in olivine (II). Ber. Bunsenges. Phys. Chem. 88, $140-145$.

O’Neill, H. S. C., Pownceby, M. I., McCammon, C. A., 2003. The magnesiowüstite: iron equilibrium and its implications for the activity-composition relations of $(\mathrm{Mg}, \mathrm{Fe})_{2} \mathrm{SiO}_{4}$ olivine solid solutions. Contributions to Mineralogy and Petrology 146, 308-325. 
O'Neill, H. S. C., Wall, V. J., 1987. The olivine-orthopyroxene-spinel oxygen geobarometer, the nickel precipitation curve, and the oxygen fugacity of the earth's upper mantle. Journal of Petrology 28, 1169 - 1191.

Padrón-Navarta, J., Hermann, J., O’Neill, H. S. C., 2014. Site-specific hydrogen diffusion rates in forsterite. Earth and Planetary Science Letters 392, 100-112.

Paterson, M. S., 1990. Rock deformation experimentation. In: Duba, A. G. (Ed.), The BrittleDuctile Transition in Rocks, Geophys. Monogr. Ser. Vol. 56. American Geophysical Union, pp. $187-194$.

Pownceby, M. I., O’Neill, H. S. C., 1994. Thermodynamic data from redox reactions at high temperatures. IV. Calibration of the $\mathrm{Re}-\mathrm{ReO}_{2}$ oxygen buffer from EMF and $\mathrm{NiO}+\mathrm{Ni}-\mathrm{Pd}$ redox sensor measurements. Contributions to Mineralogy and Petrology 118, 130 - 137.

Roberts, J. J., Tyburczy, J. A., 1993. Frequency dependent electrical properties of dunite as functions of temperature and oxygen fugacity. Physics and Chemistry of Minerals 19, $545-561$.

Rossman, G. R., 1988. Optical spectroscopy. Reviews in Mineralogy 18, 207-254.

Rubie, D. C., Karato, S., Yan, H., O’Neill, H. S. C., 1993. Low differential stress and controlled chemical environment in multianvil high-pressure experiments. Physics and Chemistry of Minerals 20, 315-322.

Sato, H., 1986. High temperature a.c. electrical properties of olivine single crystal with varying oxygen partial pressure: Implications for the point defect chemistry. Physics of the Earth and Planetary Interiors 41, 269-282.

Stocker, R. L., Smyth, D. M., 1978. Effect of enstatite activity and oxygen partial pressure on the point defect chemistry of olivine. Physics of the Earth and Planetary Interiors 16, $145-156$.

Tasaka, M., Zimmerman, M. E., Kohlstedt, D. L., 2015. Creep behavior of Fe-bearing olivine under hydrous conditions. Journal of Geophysical Research 120, 6039-6057, doi:10.1002/ 2015JB012096.

Tollan, P., Smith, R., O'Neill, H. S. C., Hermann, J., 2017. The responses of the four main substitution mechanisms of $\mathrm{H}$ in olivine to $\mathrm{H}_{2} \mathrm{O}$ activity at $1050^{\circ} \mathrm{C}$ and $3 \mathrm{GPa}$. Progress in Earth and Planetary Science in press.

Tsai, T.-L., Dieckmann, R., 2002. Variation of the oxygen content and point defects in olivines, $\left(\mathrm{Fe}_{x} \mathrm{Mg}_{1-x}\right)_{2} \mathrm{SiO}_{4}, 0.2 \leq \mathrm{x} \leq 1.0$. Physics and Chemistry of Minerals 29, 680-694, DOI $10.1007 / \mathrm{s} 00269-002-0283-1$.

Tyburczy, J. A., Du Frane, W. L., 2015. Properties of rocks and minerals - the electrical conductivity of rocks, minerals, and the Earth. In: Treatise on Geophysics. Vol. 2nd edition. Elsevier, Ch. 2.25, pp. 661-672. 
Wanamaker, B. J., 1994. Point defect diffusivites in San Carlos olivine derived from reequilibrationof electrical conductivity following changes in oxygen fugacity. Geophysical Research Letters $21,21-24$.

Wang, Z., Hiraga, T., Kohlstedt, D. L., 2004. Effect of $\mathrm{H}+$ on $\mathrm{Fe}-\mathrm{Mg}$ interdiffusion in olivine, $(\mathrm{Fe}, \mathrm{Mg})_{2} \mathrm{SiO}_{4}$. Applied Physics Letters 85, 209-211.

Watson, E. B., 1991. Diffusion in fluid-bearing and slightly-melted rocks: experimental and numerical approaches illustrated by iron transport in dunite. Contributions to Mineralogy and Petrology 107, 417-434.

Wood, B. J., Wade, J., Kilburn, M. R., 2009. Core formation and the oxidation state of the Earth: Additional constraints from $\mathrm{Nb}, \mathrm{V}$ and $\mathrm{Cr}$ partitioning. Geochimica et Cosmochimica Acta 72, 1415-1426.

Yoshino, T., Katsura, T., 2013. Electrical conductivity of mantle minerals: Role of water in conductivity anomalies. Annual Reviews of Earth and Planetary Sciences 41, 605-628. 